\title{
Heavy metal concentration levels in soil at Lake Geriyo irrigation site, Yola, Adamawa state, North Eastern Nigeria
}

\author{
Hong, Aliyu Haliru', Law, Puong Ling ${ }^{2}$, Selaman, Onni Suhaiza ${ }^{2}$ \\ ${ }^{1}$ Department of Agricultural and Environmental Engineering, Faculty of Engineering, Modibbo Adama University of Technology, Yola, \\ Nigeria \\ ${ }^{2}$ Department of Civil Engineering, Faculty of Engineering, Universiti Malaysia Sarawak, Malaysia
}

\section{Email address:}

haliruali@yahoo.com (H. A. Haliru)

\section{To cite this article:}

Hong, Aliyu Haliru, Law, Puong Ling, Selaman, Onni Suhaiza. Heavy Metal Concentration Levels in Soil at Lake Geriyo Irrigation Site, Yola, Adamawa State, North Eastern Nigeria. International Journal of Environmental Monitoring and Analysis.

Vol. 2, No. 2, 2014, pp. 106-111. doi: 10.11648/j.ijema.20140202.17

\begin{abstract}
The study assessed the physicochemical parameters and mean concentration levels of heavy metals in soil at two selected wastewater receiving sites and control site of Lake Geriyo irrigation project in order to determine the extent of heavy metal pollution due to wastewater irrigation using standard methods. The $\mathrm{pH}$ values at the River Benue, Shinko and control site soils were slightly acidic to neutral with mean value of $6.85,5.75$ and 7.0 respectively. Mean electrical conductivity values were $1.08 \mu \mathrm{s} / \mathrm{cm}, 1.54 \mu \mathrm{s} / \mathrm{cm}$ and $1.95 \mu \mathrm{s} / \mathrm{cm}$ and organic matter levels are $0.75 \%, 2.11 \%$ and $3.5 \%$. The textural classification of the soils revealed that the soils are predominantly sandy in nature with $56.4 \%, 55.6 \%$ and $50.4 \%$ sand, $20 \%, 16.0 \%$ and $19 \%$ are clay, while $24.0 \%, 28.4 \%$ and $30.0 \%$ are silt. The mean concentrations of heavy metals (Fe, $\mathrm{Zn}, \mathrm{Mn}, \mathrm{Cu}, \mathrm{Cd}, \mathrm{Cr}, \mathrm{Pb}$ and $\mathrm{Ni}$ ) recorded in River Benue site soil are $86.89 \mathrm{mg} / \mathrm{kg}, 74.38 \mathrm{mg} / \mathrm{kg}, 12.76 \mathrm{mg} / \mathrm{kg}, 15.08 \mathrm{mg} / \mathrm{kg}$, $9.83 \mathrm{mg} / \mathrm{kg}, 11.0 \mathrm{mg} / \mathrm{kg}, 7.17 \mathrm{mg} / \mathrm{kg}$ and $18.73 \mathrm{mg} / \mathrm{kg}$. Shinko site recorded concentration levels of $292.7 \mathrm{mg} / \mathrm{kg}, 309.2 \mathrm{mg} / \mathrm{kg}$, $130.9 \mathrm{mg} / \mathrm{kg}, 253.8 \mathrm{mg} / \mathrm{kg}, 199.2 \mathrm{mg} / \mathrm{kg}, 158.7 \mathrm{mg} / \mathrm{kg}$ and $74.43 \mathrm{mg} / \mathrm{kg}$ respectively, while the control site soil had concentration levels of Fe $58.48 \mathrm{mg} / \mathrm{kg}, \mathrm{Zn} 39.44 \mathrm{mg} / \mathrm{kg}, \mathrm{Mn} 7.13 \mathrm{mg} / \mathrm{kg}, \mathrm{Cu} 9.40 \mathrm{mg} / \mathrm{kg}, \mathrm{Cd} 7.62 \mathrm{mg} / \mathrm{kg}, \mathrm{Cr} 9.82 \mathrm{mg} / \mathrm{kg}, \mathrm{Pb}$ $6.28 \mathrm{mg} / \mathrm{kg}$ and $\mathrm{Ni} 17.62 \mathrm{mg} / \mathrm{kg}$. The result showed that the concentrations of heavy metals at River Benue and Shinko site soils are more polluted than the control site soil with Shinko site soil exhibiting high levels of heavy metals concentration. Comparative analysis of this study and International threshold values of heavy metals concentration levels in soil revealed that most of the parameters at Shinko site soil are elevated above the EU, USA and UK Standards. Future study is hereby recommended to focus on the impact of heavy metal concentration on irrigated vegetables as some may find their way into the food chain and cause public health hazards to consumers.
\end{abstract}

Keyword: Wastewater, Heavy Metal, Pollution, Physicochemical, Irrigation

\section{Introduction}

Soil can be defined as that unconsolidated minerals and organic material found on the immediate earth surface that serves as a natural medium for plants growth and other developmental activities (Brady and Weil, 2008). Soil also act as a key component of the natural ecosystems and environmental sustainability largely depends on a sustainable soil ecosystem and any alteration as a result of either pollution or contamination ultimately alters the ecosystems and agricultural activities are also greatly affected (Hankard et al, 2004, and Ayeni et al, 2010).

Due to rapid increase in human population, industrialization, urbanization over the years, human life styles and activities have tremendously affected the environment greatly. One of the most significant impacts is heavy metal pollution of farmland as it serves as an intimate linkage to human food chain (Niu et al, 2013). The accumulation of metals in agricultural farmland does not only decrease the productivity and quality of crops grown, but it also greatly threatens the safety of ecosystem and human health through adverse effect.

Handling and disposal of liquid waste containing heavy metals is one of the major challenge and threat to environmental wholesomeness in Nigeria where the average household waste generation is put at $0.55-0.58 \mathrm{~kg}$ per capita (SWAR, 2004). The manufacture and distribution of products such as soap, cream, batteries, perfumes, 
deodorant, metal scrap, textiles, plastics, scrap tyres and garbage as well as disposables have resulted to generation of huge volume of waste. The composition of this waste is an important source of environmental pollution and will contribute to heavy metal load in soils.

The consequences of soil contamination/pollution with heavy metals could be through direct ingestion of contaminated soil including soil particulate, dermal absorption, ingestion of groundwater contaminated by harzadous heavy metals eluted from contaminated soil, inhalation of harzadous substances emitted from contaminated soil to atmosphere, discharge of soil containing harzadous substances to municipal water ways, accumulation in aquatic ecology, ingestion by human beings, accumulation of hazardous substances in crops and livestock raised on contaminated land are some of the partway through which health impact of contaminated soil could affect public health.

At present in Zamfara State in the northwestern part of Nigeria a reported case of lead poisoning from lead contaminated soil mining was recorded in which over 2000 children and pregnant women were affected (Nigerian Daily Trust, 2013). Lead that contaminates the environment is largely deposited by dust into soil and water and is taken up by or exists on the surfaces of plants which are grazed by livestock, cattle, sheep, and horses which are good indicators of pollution on vegetation (Debackere, 1983). Bala et al, 2013 reported high concentration of lead in liver, kidney and muscle of slaughtered cattle at Jos Central Abattoir and attributed it to grazing on plant and feeds from lead contaminated soil. Heavy metal accumulation in soil is of increasing concern because of the potential of risk of its uptake and transfer into food chain. Therefore soil as an environmental resource should be protected from further degradation and contamination from pollutants especially heavy metals so as to produce healthy food for the worlds increasing population. The objective of this work, therefore, was to determine the concentration of heavy metals in soil at Lake Geriyo irrigation site that has been on wastewater effluent irrigation during the dry season for more than ten years.

\section{Materials and Methods}

\subsection{Study Area}

Adamawa State is located in the northeastern part of Nigeria with a population of 3,737,223 people and land mass of $36,917 \mathrm{~km}^{2}$. Yola (Jimeta) the Adamawa State capital is located between Longitudes $12^{\circ} 26^{\prime} \mathrm{E}$ and Latitude $9^{\circ} 16^{\prime} \mathrm{N}$ (http://www.en.wikipedia.org/wiki/jimeta) along the banks of River Benue (Adebayo, 1999). Lake Geriyo lies between Longitude $12^{\circ} 00^{\prime}$ and $12^{\circ} 28^{\prime}$ East of Greenwich and Latitude $9^{\circ} 16^{\prime}$ and $9^{\circ} 19^{\prime}$ North of the equator. It has devoted land area of 1200 hectares for dry season irrigation (Fig 1). The state is in the Sahel region of Nigeria generally Semi arid with low rainfall, low humidity and high temperature. The area experiences two distinct wet and dry seasons, the wet season starts from April to October while the dry season starts from November to April. Mean daily temperature fluctuates with season from $25^{\circ} \mathrm{C}$ to $45^{\circ} \mathrm{C}$ and mean annual rainfall received is in the range of $(250-1000 \mathrm{~mm})$. The climate is characterized by high evapotranspiration especially during dry season (Adebayo, 1999). Jimeta/Yola the State capital has an estimated population of 600,000 people (NPC, 2006).

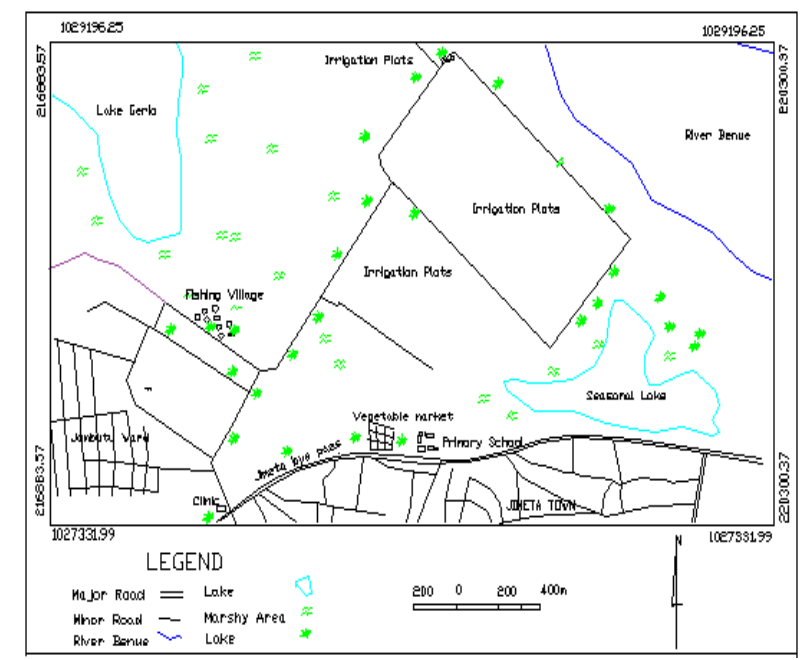

Fig 1. Lake Geriyo Irrigation Sites.

\subsection{Soil Sampling}

A detailed soil reconnaissance survey was conducted where two sites were selected for this research namely: River Benue plot wastewater irrigation site (RBS), Shinko municipal wastewater irrigation site (SHS) and Federal university of Technology Yola research farm soil believed not to be contaminated and uses clean water (tape water) irrigation was selected as control to gauge the difference in the two wastewater receiving sites. A representative composite soil samples was taken from Shinko site, river Benue site and the control site at a depth of $0-30 \mathrm{~cm}$ each using soil sampling spiral auger. The samples were taken in labeled polytene bags to differentiate the sampling points, dried, grounded and sieved through $2 \mathrm{~mm}$ size sieve and taken to the laboratory for analysis.

\subsection{Analytical Procedure}

The parameters that were analyzed in the soil samples include, soil particle size distribution, $\mathrm{pH}$, electrical conductivity (EC), organic matter content (OM), trace and heavy metals (Fe, $\mathrm{Zn}, \mathrm{Mn}, \mathrm{Cu}, \mathrm{Cd}, \mathrm{Cr}, \mathrm{Pb}$ and $\mathrm{Ni}$ ). The soil particle distribution analysis was carried out by adopting the Bouyoucos Hydrometer method where the textural classification was interpreted on the USDA triangle into percentage sand, silt and clay. The analytical method adopted for testing soil $\mathrm{pH}$ was the potentiometric method using $\mathrm{pH}$ meter (model Jenway 3310) well calibrated using buffers of $\mathrm{pH} 4.0,7.0$ and 10.0 and the electrode immersed in 1:1 soil/water solution. Conductivity was also measured in 1:1 soil/water extract using Jenway conductivity meter 
(4510 model). Soil organic matter was determined by the Walkey - Black procedure (Bai et al., 2010)

\subsection{Digestion of Soil Samples}

The soil samples initially collected from the two wastewater irrigated site and the tape water sites in triplicate, were oven dried, sieved through $2 \mathrm{~mm}$ mesh size and stored at room temperature. The soil samples was extracted by taken $2 \mathrm{~g}$ oven dried soil into a Pyrex beaker, $15 \mathrm{ml}$ of aqua regia (hydrochloric/nitric acid) was added and the mixture was allowed to stand for 16 hours at room temperature, and then followed by boiling under reflux for 2 hours at $160^{\circ} \mathrm{C}$. The extract was filtered and clarified and make up to the volume with nitric acid.

\subsection{Heavy Metal Analysis}

In the acid extract, the concentration of trace and heavy metals (Fe, $\mathrm{Zn}, \mathrm{Mn}, \mathrm{Cu}, \mathrm{Cd}, \mathrm{Cr}, \mathrm{Pb}$ and $\mathrm{Ni}$ ) were determined by using fast sequential Atomic Absorption spectrometer (AA240FSModel) after calibration and selection of the various wavelengths at which all the heavy metal are eliminated and tested. To ensure quality control, blank reagent and standard reference solution of all the trace and heavy metals in soil were included in each sample batch to verify the accuracy and precision of the digestion procedure and subsequent analysis.
The recorded physicochemical and heavy metal data were analyzed using SPSS (17.0) statistical software and all measurement were expressed in terms of mean values. Also Microsoft excel software (Microsoft 2003) was used to evaluate graphically.

\section{Results and Discussions}

Table 1 presents the results of physicochemical properties of soils recorded at River Benue, Shinko and the control site. The $\mathrm{pH}$ value recorded at the RBS site ranged from $6.4-7.3$ with mean of 6.85 , while that of SHS site ranged from $5.4-6.1$ with mean of 5.57. The control site $\mathrm{pH}$ ranged from $6.5-7.5$ with mean of 7.0. The result of $\mathrm{pH}$ at the RBS site exhibited slightly acidic to slightly neutral, while at the SHS site the $\mathrm{pH}$ value is acidic. The control soil was neutral. The acidic nature of soil at the SHS site could influence the mobility and bioavailability of heavy metals in soil (Jan et al., 2010). Kashem et al, 2006, and Khan et al, 2010 also affirmed and reported high $\mathrm{Cd}$ concentration at low $\mathrm{pH}$, while increased bioavailability is also reported at low pH by (Sukreeyapongse et al., 2002). Thus, $\mathrm{pH}$ as a key parameter controlling heavy metal transfer behavior in soils, the observed values in this study may have implications on the availability and uptake of metal by plant grown on these soils.

\subsection{Data Analysis}

Table 1. Physicochemical Properties of Soil at River Benue, Shinko and Control Sites.

\begin{tabular}{ccccccccccc}
\hline Sites & $\begin{array}{c}\text { Soil depth } \\
(\mathbf{c m})\end{array}$ & $\begin{array}{c}\text { pH } \\
\text { range }\end{array}$ & mean & $\begin{array}{c}\text { EC }(\boldsymbol{\mu s} / \mathbf{c m}) \\
\text { range }\end{array}$ & mean & $\begin{array}{c}\text { OM (\%) } \\
\text { range }\end{array}$ & $\begin{array}{c}\text { Sand } \\
\text { mean }\end{array}$ & $\begin{array}{c}\text { Clay } \\
(\%)\end{array}$ & $\begin{array}{c}\text { Silt } \\
(\%)\end{array}$ & $\begin{array}{c}\text { Textural } \\
(\%)\end{array}$ \\
Class
\end{tabular}

RBS $=$ River Benue site, $\mathrm{SHS}=$ Shinko site, $\mathrm{EC}=$ Electrical conductivity, $\mathrm{OM}=$ Organic matter

The electrical conductivity values at RBS site ranged from $0.56-1.60 \mu \mathrm{s} / \mathrm{cm}$ with mean value of $1.08 \mu \mathrm{s} / \mathrm{cm}$ and at SHS site it ranged from $0.88-2.20 \mu \mathrm{s} / \mathrm{cm}$ and mean of $1.54 \mu \mathrm{s} / \mathrm{cm}$. The control soil had a range of $0.90-3.0 \mu \mathrm{s} / \mathrm{cm}$ and mean of $1.95 \mu \mathrm{s} / \mathrm{cm}$. Higher value of EC were recorded at SHS site and the control site. The values are however lower than the values reported by Oviasogie et al., (2007) for physicochemical properties of soil in a foam manufacturing industry in Nigeria. The low conductivity values recorded in this study imply that there is low level of organic salts in these soils.

The levels of mean percentage organic matter in RBS soil ranged from $0.20-1.30 \%$ and mean value of $0.75 \%$, while SHS soil organic matter level is in the range of $1.90-$ $2.30 \%$ and the mean value is $2.11 \%$. The control soil mean percentage organic matter level ranged from $3.0-4.0 \%$ with mean of $3.5 \%$ (Table 1). Higher mean percentage organic matter was recorded in SHS soil and the control soil. Brady and Weil (2008) classified organic matter level of soil into classes: $<0.4 \%$ organic matter of soil as very low, $1.0-1.5 \%$ as moderate organic matter soil and $>2.0 \%$ as high organic matter soil. Based on this, all the soils under consideration fell into the class of moderate to high organic matter level soils. The values of the percentage organic matter observed was consistent with those reported in another related study (Osenwata, 2009). Organic matter in soil and sediments plays a key role in influencing the physical, chemical, distribution, mobility and availability of cat ions and anions in the natural soil and water environment (Osakwe, 2013).

The results of particle size distribution and textural classification of soil under study revealed that RBS had $56.4 \%$ sand, $20.0 \%$ clay, and $24.0 \%$ silt (Table 1 ), the textural class was sandyclayloam (SCL), while SHS soil had $56.6 \%$ sand, $16.0 \%$ clay, and $28.4 \%$ silt, the texture class is also sandyclayloam. The control soil had $50.4 \%$ sand, $19.6 \%$ clay and $30.0 \%$ silt and texture was loam soil. The soil particle size analysis indicated that all the soils are predominantly sandy in nature at $0-30 \mathrm{~cm}$ depth meaning that water can infiltrate faster in these soils owing to much 
larger sand particles and pore spaces between soil particles, hence frequent application of water and low water retention capacity of this soil is expected under irrigation.
Application of wastewater on this soil under irrigation means that crops can easily absorbs heavy metals in this water depending on the wastewater composition.

Table 2. Heavy metals concentration levels of River Benue and Shinko irrigation sites.

\begin{tabular}{|c|c|c|c|c|c|c|}
\hline \multirow{2}{*}{$\begin{array}{c}\text { Heavy metals } \\
(\mathrm{mg} / \mathrm{kg})\end{array}$} & \multicolumn{2}{|c|}{ RBS Site } & \multicolumn{2}{|c|}{ SHS Site } & \multicolumn{2}{|c|}{ Control Site } \\
\hline & Range & mean & Range & mean & Range & mean \\
\hline $\mathrm{Fe}$ & $71.0-109$ & 86.89 & $56.0-506$ & 292.7 & $40.0-88.0$ & 58.48 \\
\hline $\mathrm{Zn}$ & $61.0-88.4$ & 74.38 & 123.0426 .0 & 309.2 & $30-56.1$ & 39.44 \\
\hline $\mathrm{Mn}$ & $9.0-18.1$ & 12.78 & $31.1-367.0$ & 130.9 & $3.0-13.0$ & 7.13 \\
\hline $\mathrm{Cu}$ & $10.0-20.2$ & 15.08 & $135.0-400$ & 253.8 & $5.0-19.1$ & 9.40 \\
\hline $\mathrm{Cd}$ & $9.0-11.1$ & 9.83 & $86.0-506.2$ & 239.2 & $4.0-10.1$ & 7.62 \\
\hline $\mathrm{Cr}$ & $10.0-13.0$ & 11.0 & 145.0290 .1 & 199.2 & $7.0-12.0$ & 9.82 \\
\hline $\mathrm{Pb}$ & $6.0-8.1$ & 7.17 & $110.2-269.0$ & 158.7 & $4.0-8.0$ & 6.28 \\
\hline $\mathrm{Ni}$ & $17.0-20.1$ & 18.73 & $23.0-130.1$ & 74.43 & $15.0-20.0$ & 17.62 \\
\hline
\end{tabular}

RBS $=$ River Benue Soil, SHS $=$ Shinko Soil

The results of trace and heavy metals concentration recorded at RBS, SHS sites and the control site is presented in Table 2. The results showed that heavy metal concentrations were generally higher at SHS soil than at RBS and the control soil. Previous studies have indicated that surface soils are better indicators of metallic pollution (Amusan et al, 2005). This is expected since almost all the wastewater from small scale industries, hospitals, abattoir are directly disposed on this soil, the site have some high levels of heavy metal enrichment than the other soils (Table 2).

The mean concentration of Fe ranged from 71.0 - 109 $\mathrm{mg} / \mathrm{kg}$ and mean of $86.89 \mathrm{mg} / \mathrm{kg}$ in RBS site, while $56.0-$ $506 \mathrm{mg} / \mathrm{kg}$ and mean of $292.7 \mathrm{mg} / \mathrm{kg}$ was recorded for SHS site soil. The control site soil had a range of $40-$ $88.0 \mathrm{mg} / \mathrm{kg}$ with mean value of $58.48 \mathrm{mg} / \mathrm{kg}$. SHS site soil exhibited significantly higher value of Fe than RBS and the control site soil. Similar levels of Fe have been reported by (Osakwe, 2013). However, abundance of Fe in this soil could be attributed to the presence of some automobile scraps, mechanic workshop wastewater, wears and tears of automobile parts. Excessive levels of $\mathrm{Fe}$ in soil used for crop production might result in high levels of $\mathrm{Fe}$ in produce which may enter food chain to cause vomiting, nausea, anxiety, tension, brain hemorrhage, metabolic disorder and cardiac arrest (Kaur and Mehra, 2012).

The concentration levels of $\mathrm{Zn}, \mathrm{Mn}$ and $\mathrm{Cu}$ in RBS soil ranged from $61.0-88.4 \mathrm{mg} / \mathrm{kg}, 9.0-18.1 \mathrm{mg} / \mathrm{kg}$, and $10.0-$ $20.2 \mathrm{mg} / \mathrm{kg}$ and mean values of $74.38 \mathrm{mg} / \mathrm{kg}, 12.78 \mathrm{mg} / \mathrm{kg}$, and $15.08 \mathrm{mg} / \mathrm{kg}$ respectively. SHS recorded concentration range of $123.0-426.0 \mathrm{mg} / \mathrm{kg}, 31.1-367.0 \mathrm{mg} / \mathrm{kg}$ and 135.0 - $400.0 \mathrm{mg} / \mathrm{kg}$ with mean values of $309.2 \mathrm{mg} / \mathrm{kg}$, $130.9 \mathrm{mg} / \mathrm{kg}$ and $253.8 \mathrm{mg} / \mathrm{kg}$. At the control soil concentration of $\mathrm{Zn}, \mathrm{Mn}$ and $\mathrm{Cu}$ ranged from $30-$ $56.1 \mathrm{mg} / \mathrm{kg}, 3.0-13.0 \mathrm{mg} / \mathrm{kg}$ and $5.0-19.1 \mathrm{mg} / \mathrm{kg}$, their observed mean values are $39.44 \mathrm{mg} / \mathrm{kg}, 7.18 \mathrm{mg} / \mathrm{kg}$ and $9.40 \mathrm{mg} / \mathrm{kg}$. The results revealed that the concentrations significantly higher at SHS and RBS soil as compared to the control soil (Fig 1 and 2). The concentrations of $\mathrm{Cu}$ and $\mathrm{Zn}$ observed in this study are higher than that reported in Osakwe, 2013. Copper in soil could result from metal bearing wears and Babbitt metal bushings. Although $\mathrm{Cu}$ is an essential element but at higher concentration in soil as discovered in this study crop could absorb it to phytotoxic level to cause anemia, gastrointestinal disorder and also leads to liver and kidney malfunctioning in critical cases(USEPA, 1999). The presence of $\mathrm{Zn}$ also could be due to corrosion of metal parts of automobiles. Excessive concentration of $\mathrm{Zn}$ in food may result in health disorder such as diarrhea, vomiting and abdominal pain (Adaipo et al, 2005).

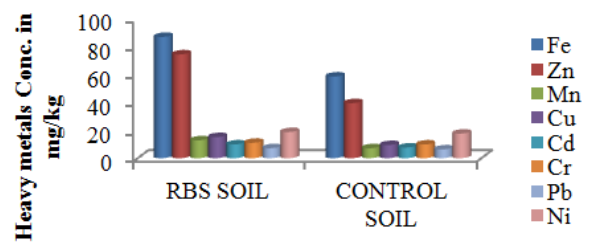

Fig 1. Variation of Heavy metal Concentration in RBS Soil and Control soil.

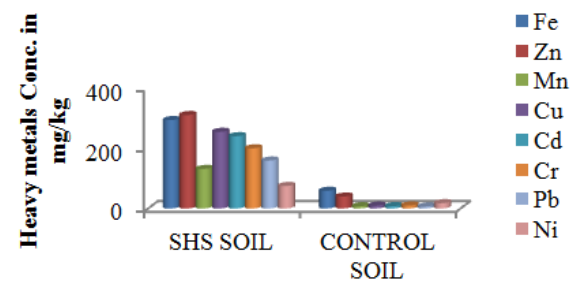

Fig 2. Variation of Heavy metal Concentration in SHS Soil and Control soil.

The concentration levels of $\mathrm{Cd}, \mathrm{Cr}$, and $\mathrm{Pb}$ in $\mathrm{RBS}$ soil ranged from $9.0-11.1 \mathrm{mg} / \mathrm{kg}, 10.0-13.0 \mathrm{mg} / \mathrm{kg}$ and $6.0-$ $8.1 \mathrm{mg} / \mathrm{kg}$ respectively. Their mean values are $9.83 \mathrm{mg} / \mathrm{kg}$, $11.0 \mathrm{mg} / \mathrm{kg}$ and $7.17 \mathrm{mg} / \mathrm{kg}$. In SHS soil, the value range between $86.0-506 \mathrm{mg} / \mathrm{kg}, 145.0-290.1 \mathrm{mg} / \mathrm{kg}$ and for $\mathrm{Pb}$ $110.2-269.0 \mathrm{mg} / \mathrm{kg}$ was recorded. Their mean values are $239.2 \mathrm{mg} / \mathrm{kg}, 199.2 \mathrm{mg} / \mathrm{kg}$ and $158.7 \mathrm{mg} / \mathrm{kg}$. At the control site soil, the parameters ranged from $4.0-10.1 \mathrm{mg} / \mathrm{kg}, 7.0-$ $12.0 \mathrm{mg} / \mathrm{kg}$ and $4.0-8.0 \mathrm{mg} / \mathrm{kg}$. The mean values are $7.62 \mathrm{mg} / \mathrm{kg}, 9.82 \mathrm{mg} / \mathrm{kg}$ and $6.28 \mathrm{mg} / \mathrm{kg}$. The values of $\mathrm{Cd}$, $\mathrm{Cr}$ and $\mathrm{Pb}$ showed that RBS and SHS soil are highly enriched with the heavy metals as compared to the control soil (Fig 1 and 2). Nickel concentrations in both RBS and SHS soil ranged from $17.0-20.1 \mathrm{mg} / \mathrm{kg}, 23.0-130.1 \mathrm{mg} / \mathrm{kg}$ 
with mean of $18.73 \mathrm{mg} / \mathrm{kg}$ and $74.43 \mathrm{mg} / \mathrm{kg}$. The values of $\mathrm{Ni}$ at the control site soil range from $15.0-20.0 \mathrm{mg} / \mathrm{kg}$ with mean value of $17.62 \mathrm{mg} / \mathrm{kg}$. Generally, higher levels of $\mathrm{Cd}$, $\mathrm{Cr}$ and $\mathrm{Pb}$ observed in these soils as compared to the control soil revealed an elevated level of heavy metals in agricultural soils. The values of $\mathrm{Cd}, \mathrm{Cr}$ and $\mathrm{Pb}$ are higher than that reported in Osakwe, 2013. This could probably be due to the presence of lead- based, chromium and cadmium discarded batteries which have enriched the soils. The resultant effect of heavy metals enriched into agricultural soil is that crop might absorb them to a higher level that could expose consumers of the crop to health risk. Lead poisoning as reported by Kaur and Mehra, 2012 causes gastrointestinal neuromuscular and nervous system disorder and can also damage liver and kidney, reduce formation of hemoglobin and infertility and defects at birth.

Table 3. Comparison between International threshold values for heavy metals concentration level in soil regulatory systems (CCME, 2003) and present work

\begin{tabular}{|c|c|c|c|c|c|c|}
\hline Heavy metals & $\mathbf{E U}$ & USA & Canada & UK & RBS Site & SHS Site \\
\hline $\mathrm{Cd}(\mathrm{mg} / \mathrm{kg})$ & 3.0 & 3.0 & 19.5 & 1.4 & 9.83 & 239.2 \\
\hline $\mathrm{Zn}$ & 300 & $200-300$ & 1400 & 200 & 74.38 & 309.2 \\
\hline $\mathrm{Cr}$ & 180 & 400 & 1500 & 6.4 & 11.0 & 199.2 \\
\hline $\mathrm{Cu}$ & 140 & $80-200$ & 170 & 63 & 15.08 & 253.8 \\
\hline $\mathrm{Pb}$ & 300 & 300 & 150 & 70 & 7.17 & 158.7 \\
\hline $\mathrm{Ni}$ & 75 & $50-110$ & 210 & 50 & 18.73 & 74.43 \\
\hline
\end{tabular}

$\mathrm{EU}=$ European Union, USA = United State of America, UK = United Kingdom

Table 3: Presents comparison of heavy metals concentration in soils between the present work and International regulatory systems for threshold values for heavy metals concentration levels in soils.

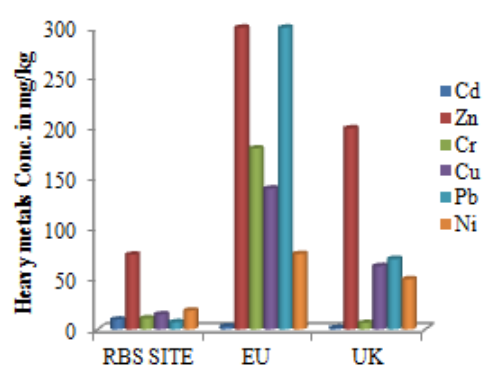

Fig 3. comparison of Heavy metal Concentration in RBS Site and EU,UK Standards.

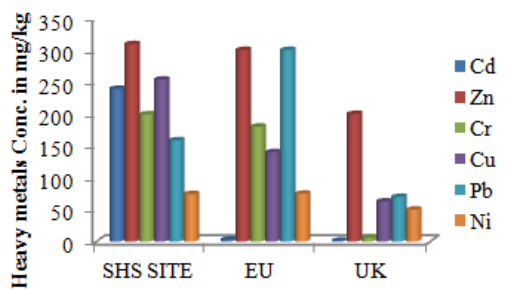

Fig 4. Comparison of Heavy metals concentration in SHS Site and EU, UK Standards.

Mean concentration values of $\mathrm{Cd}$ recorded at RBS and SHS site soil were $9.83 \mathrm{mg} / \mathrm{kg}$ and $239.2 \mathrm{mg} / \mathrm{kg}$, comparatively, the values are higher than EU, USA and UK standards of $3.0 \mathrm{mg} / \mathrm{kg}$ and $1.4 \mathrm{mg} / \mathrm{kg}$ at both sites. Similarly, the concentrations values of $\mathrm{Cr}, \mathrm{Cu}, \mathrm{Pb}$ and $\mathrm{Ni}$ recorded at RBS and SHS site soil with values of $11.0 \mathrm{mg} / \mathrm{kg}$, $199.2 \mathrm{mg} / \mathrm{kg}, 15.08 \mathrm{mg} / \mathrm{kg}, 253.8 \mathrm{mg} / \mathrm{kg}, 158.7 \mathrm{mg} / \mathrm{kg}$ and $158.7 \mathrm{mg} / \mathrm{kg}$ are higher than $6.4 \mathrm{mg} / \mathrm{kg}, 63.0 \mathrm{mg} / \mathrm{kg}$, $70.0 \mathrm{mg} / \mathrm{kg}$ and $50.0 \mathrm{mg} / \mathrm{kg}$ values specified by UK standard (Fig 3). Generally, the comparison revealed that the concentration of heavy metals at RBS and SHS sites soil was highly elevated above the maximum permissible level for soils standard obtainable from European Union and the United Kingdom (Fig 4). This comparison showed that some degrees of contamination of soil at the two sites are evident which urgently require an intervention measures as long as irrigation of edible crops are grown on these soil.

On the whole, the heavy metals concentrations trends in soil at the RBS and SHS sites are in the order: $\mathrm{Fe}>$ $\mathrm{Zn}>\mathrm{Ni}>\mathrm{Cu}>\mathrm{Mn}>\mathrm{Cr}>\mathrm{Cd}>\mathrm{Pb}$ and $\mathrm{Zn}>\mathrm{Fe}>\mathrm{Cu}>\mathrm{Cd}>$ $\mathrm{Cr}>\mathrm{Pb}>\mathrm{Mn}>\mathrm{Ni}$.

\section{Conclusion}

The results of physicochemical analysis indicate that the soils were slightly acidic to neutral, EC values imply the presence of considerable level of inorganic salt, while the soil have an appreciable organic matter level to influence the transfer and bioavailability of heavy metals enrichment from wastewater into soil. The concentration levels of some heavy metals in soil are elevated above the control soil and the established international guidelines for heavy metals in soils. SHS site soil is more polluted than RBS soil when compared to the control soil which might be due to industrial and anthropogenic activities close to the study area may be responsible for the observed soil pollution. Future study are hereby recommended to focus on the impact of these heavy metals on irrigated vegetables as some may find their way into food chain and cause public health hazards on consumers.

\section{References}

[1] Adaipo, E.O, Kaizer, A.N. and Osakwe, S.A. Distribution of heavy metals in subsurface soils In Abraka and environs, southwestern Nigeria. Afr. Science, 2005, 6(1) $29-33$

[2] Amusan,A.A, Ige, D.V. and Olawale, R. Characteristics of soils and crop uptake of metals in Municipal waste dumpsites in Nigeria. J. Hum. Ecol. 2005, 17(3) $167-171$ 
[3] Ayeni,O.O, Ndakidemi P.A, Snyman R.G, Odendaal JP (2010). Chemical, biological and Physiological indicators of metal pollution in wetlands. Sci. Res. Essays, 5(15): $1938-$ 1949.

[4] Brady NC, Weil RR (2008). The Nature and properties of soils. Fourteenth Edition, Pearson Education Inc; Upper Saddle River, New Jersey, pp 65.

[5] Bala, A. Mohammad, L.U, Pewan, S.B, Ahmed, Mohammad, M, Junaidu, A.U, Salihu, M.D, Magaji, A.A, Faleke, O.O, Agaie, Anzaku, S.A and Saulawa, M.A (2013). Determination of Lead Residue in Kidney, Liver, and Muscles of Slaughtered Cattle in Jos Central Abattoir, Plateau State, Nigeria. Journal of Environmental Science, Toxicology And Food Technology. 7(6): Pp 48 - 51

[6] Bai, J., Yany, Z., Cui, B., Gao, H., Ding, Q., (2010). Some heavy metals distribution in Wetland soil under different land use types along a typical plateau lake, China Soil Tillage Res. 106, $344-348$.

[7] Canadian Council of Ministers of the Environment CCME (2003). Canadian Soil quality Guidelines for the protection of environmental and human health. Summary of a Protocol for the Derivation of Environmental and Human Health Soil Quality Guidelines. In: Canadian Environmental quality guidelines, Chapter 7, Canadian Council of Ministers of the Environment, Winnipeg.

[8] Debackere M (1983). Environmental Pollution: The animal as a source indicator and Transmitter. In: Veterinary pharmacology and toxicology. $2^{\text {nd }}$ Edition Westport, CT, AVI Publishing Co., Pp: $595-608$.

[9] Hankard PK, Svndsen C, Wright J, Weinberg C, Fishwick SK, Spurgeon DJ, Weeks JM (2004). Biological assessment of contaminated land using earthworm biomarkers in Support of chemical analysis Sci. Total Environ. 330:9- 20.

[10] Jan, F.A., Ishaq, M., Khan, S., Ihsanullah, I., Ahmad, I., Shakirullah, M., (2010) A Comparative study of human health risks via consumption of food crops grown on Wastewater irrigated soil (Peshawar) and relatively clean water irrigated soil (Lower Dir). J. Hazard. Mat. 179, 612621.

[11] Kasha, M.D.A., Singh,B.R., Kawai, S., (2006). Mobility and distribution of cadmium, nickel And zinc in contaminated soil profile from Bangladesh. Nutr. Cycl. Agroecosyst. 77, $187-198$.

[12] Khan, S., Rehman, S., Khan A.Z., Khan, M.A., Shah, M.T (2010), Soil and vegetable Enrichment with heavy metals from geological sources in Gilgit, northern Pakistan. J. Eco. And Environmental Safety 73: 1820 - 1827.

[13] Kaur, S. and Mehra, P. Assessment of heavy metals in summer and winter seasons in River Yamuna segment flowing through Delhi, India. J. Environ. Ecol., 2012, 3(1) 1 $-17$

[14] National Population Commission (2006). Nigerian National Census conducted in the year 2006.

[15] Nigerian Daily Trust Newspaper published on Wednesday $29^{\text {th }}$ May 2013 accessed on www.Dailytrust.info

[16] Niu, L., Yang, F., Xu, C., Yang, H., Liu, W. (2013). Status of metal accumulation in Farmland soils across China: From distribution to risk assessment. J. of Environmental Pollution 176: 55 - 62 .

[17] Oviasogie, P.O. and Omoruyi, E. (2007) Levels of heavy metals and physicochemical Properties of soil in a foam manufacturing industry. J. Chem. Soc. Nig, 32 (1):102 - 106

[18] Osenwata, O.I. (2009). Effects of abattoir effluent on the physical and chemical properties of Soils. Environ. Monit. Assess., $1058-1068$

[19] Osakwe, S.A. (2013). Assessment of the effects of wood processing industries in selected Parts of Delta State, Nigeria, on the soils and vegetables in their vicinities. JOSRJ. Appl. Chem, 3(3): $22-33$.

[20] Sukreeyapongse, O., Holm, P.E., Srobel, B.W., Panichsakpatana, S., Magid, J., Hansen, H.C.B., (2002). Ph dependence release of cadmium, copper, and lead from natural And sludge- amended soils. J. Environ. Quality 31, $1901-1909$

[21] Solid Waste Audit Report SWAR, (2004)

[22] USEPA, (1999). National primary drinking water regulation, United State Environmental Protection Agency. 